ronment and natural resources, 22-23 March 2005. UKM and Ministry of Natural Resources and Environmental, Malaysia.

Rahayu, S., S. S. Lee, A. S. Nor Aini, S. Gizan and S. S. AHMAD (2006): Infection of Falcataria moluccana (Miq.) Barneby \& Grimes seedling by gall rust fungus Uromycladium spp. is associated with a reduction in growth and survival. Pages 243-247. Proceeding of International Post Graduate Student Conference. Penang: University Science Malaysia (USM), Malaysia.

RAHAYU, S. (2007): Gall rust disease of Falcataria moluccana in Sabah, Malaysia PhD. Thesis. Universiti Putra Malaysia, Malaysia.

SCHUBERT, T. R. (1985): Preliminary results of eucalyptus/legume mixtures in Hawaii. NFTRR 3: 65-66.
STINE, R. A. (1999): Reducing the impact of blister rust on white pine in Minnesota. Principle investigator. Final Report. Minnesota. 28 pp.

Stubbs, R.W., J. M. Prescott, E. E. SAari and H. J. Dubin (1986): Cereal Disease Methodology Manual. CIMMYT, Mexico. 46 pp.

Toothill, E. (1984): Dictionary of Botany. Penguin. Great Britain.

WAC (World Agro forestry Centre). (2005): Agro forestry Database. www.worldagroforestry.org/Sites/TreeDBS/ Aft/Print.cfm?SpID=171. Accessed on 12 February 2005. Wagner, W. L., D. R. Herbst and S. H. Sohmer (1999): Manual of the Flowering Plants of Hawaii. 2 vols. Bishop Museum Special Publication 83, University of Hawaii and Bishop Press, Honolulu, Hawaii.

\title{
Characterization of Juglans nigra (L.), Juglans regia (L.) and Juglans $x$ intermedia (Carr.) by SSR markers: a case study in Italy
}

\author{
By P. Pollegioni ${ }^{1)}$, K. Woeste ${ }^{3)}$, A. MajoR ${ }^{2)}$, G. Scarascia Mugnozza ${ }^{1)}$ and M. E. Malvolti ${ }^{\left.1),{ }^{*}\right)}$
}

(Received $18^{\text {th }}$ January 2008)

\begin{abstract}
Juglans nigra and Juglans regia are economically important species in Europe, Asia and North America. Natural hybrids between the two species, known as Juglans x intermedia (Carr), are valued for timber production. We tested ten nuclear microsatellite markers to (1) identify new J. x intermedia hybrids and characterize their parentage species J. regia and J. nigra (2) detect $J$. nigra genotypes with a spontaneous crossing ability with $J$. regia in a mixed Italian population. This study was also designed to confirm the transferability of ten black walnut SSR loci to Persian walnut All ten microsatellites amplified in both species, producing fragments of variable size; eight $(7.14 \%)$ were common, 68 $(60.7 \%)$ amplified in J. nigra and $36(32.1 \%)$ in J. regia only (private alleles). Indices of genetic diversity revealed high level of variability. The Principal Coordinate Analysis on the basis of total 112 alleles divided the total sample set into three main groups: J. nigra, J. regia and J. x intermedia hybrids. Performing the microsatellite fingerprinting, a triploid hybrid plant
\end{abstract}

\footnotetext{
1) C.N.R. Institute of Agro-environmental and Forest Biology, viale Marconi 2, 05010, Porano, Terni, Italy. E-mail: paola. pollegioni@ibaf.cnr.it; mimi@ibaf.cnr.it

2) Molecular Tassonomy Laboratory, Hungarian Natural History Museum, Baross u. 13, 1088 Budapest, Hungary. E-mail: major@nhmus.hu

$\left.{ }^{3}\right)$ U.S.D.A. Forest Service, Hardwood Tree Improvement and Regeneration Center, Department of Forestry and Natural Resources, Purdue University, 715 West State Street, West Lafayette IN 47907-2061. E-mail: kwoeste@fs.fed.us

*) Corresponding author: Maria Emilia Malvolti. Tel. 0039 0763374913. Fax 0039 0763374980. E-mail: mimi@ibaf.cnr.it
}

with two genome parts of J. nigra and one part of J. regia was identified. The cytological analysis proved this triploid state showing 48 somatic chromosomes. The mother testing analysis of the 7 diploid hybrids by exclusion method indicated one putative hybridogenic mother plants. The sequence analysis of amplified fragments confirmed the cross-species amplification of SSR. Inter-specific differences between alleles were due not only to simple changes in the number of repeats but also to mutations in the flanking regions.

Key words: Juglans, interspecific hybrids, microsatellites, cross-species amplification, sequencing.

\section{Introduction}

Juglans nigra (Eastern black walnut) and Juglans regia (common or Persian walnut) are highly economically important species in Europe, Asia and North America. The Persian walnut, an indigenous species in Eurasia from the Balkans to southwest China, is cultivated throughout the temperate regions of the world for its high quality wood and edible nuts. Black walnut, native to the Eastern part of North America, is a fast growing species with a dark-colored wood used in the manufacture of furniture and other wood products. Beginning in the $17^{\text {th }}$ century, J. nigra was imported from the Eastern and Central hardwood forests of the United States to the European continent for ornamental purposes, and subsequently for its rapid growth. In Italy the black walnut is usually found in private and public parks of Pianura Padana where is also used for reforestation and recovering degradated areas (FENAROLI, 1975). Both 
common and black walnut are sensitive to soil conditions, developing best on deep, well-drained, moist and fertile soils but they differ in response and to biotic and abiotic factors (MCGRANAHAN and LESLIE, 1990).

Both species are monoecious and heterodichogamous, with the same number of chromosomes $(2 n=32)$. The mating system of black and Persian walnut is predominantly outcrossing, as they are wind pollinated, although under particular environmental conditions self-pollination is possible. Although phylogenetic analysis based on nuclear RFLP, matK and ITS sequence has demonstrated that black walnut and Persian walnut belong to different sections of genus Juglans, Rhysocaryon and Dioscaryon respectively (STANFORD et al., 2000), a hybrid between them, Juglans $\mathrm{x}$ intermedia (Carr), can occur naturally. However J. nigra pistillate flowers matures usually later then $J$. regia pollen catkins. Thus, no all plants could produce hybrids and the hybridazation between black and Persian walnut is not common. It requires the overlapping of the bloom time for the two parental trees and an appropriate temperature for pollen germination and penetration though the stigma and the style to the J. nigra ovary (LuZA et al., 1987). The identification and selection of two hybridogenic parents is the first step to obtain hybrid progeny.

Compared to the parental species, most J. x intermedia hybrids show increased vegetative vigour, distinct disease resistance, good wood quality, and greater winter-hardiness than Juglans regia (FADY et al., 2003). For these reasons there is a great demand for J. x intermedia for forestry, especially in Northern Europe. The characterization of new $J$. $\mathrm{x}$ intermedia hybrids and the detection of $J$. nigra genotypes with a spontaneous crossing ability with J. regia is useful for selection and breeding programme on Juglans spp.

In the past, several methodologies have been used to distinguish between J. nigra and J. regia and to identify French and German inter-specific hybrids. They were based on morphological traits (JAY-ALLEMAND et al., 1990), biochemical markers such as isozymes (HussendoRFER, 1999) and PCR-markers as RAPDs (MALvolti et al., 1997). Recently Woeste et al. (2002) developed a panel of thirty nuclear microsatellites in J. nigra L. as markers for a wide range of genetic investigations. A subset of these markers has been successfully used for clonal identification (RoBICHAUD et al., 2006) and a broad-scale study of the genetic structure of J. nigra populations in the Central Hardwood Region of the United States (VICTORY et al., 2006). At the same time, a subset of microsatellites were also selected and screened in J. regia L. as a starting point for the genetic characterization of "Sorrento" variety (FORONI et al., 2005) and some walnut cultivars (DANGL et al., 2005); Pollegioni et al. (2006) carried out a preliminary study of some hybrids (J. nigra x J. regia). Microsatellite, known as simple sequence repeats (SSRs), are short (1-6 bp long), tandem repeated DNA sequences widely dispersed throughout eukaryotic genomes. These markers require the design of primers for the conserved flanking regions of the microsatellite and the PCR amplification of the repeat region. The single-locus markers are characterized by hypervariability, abun- dance, high reproducibility, Mendelian inheritance, and co-dominant expression. These positive features make them suitable tools for parentage analysis (STREIFF et al., 1999) and molecular fingerprinting of hybrids (NANDAKUMAR et al., 2004). Nevertheless, a detailed study of the inter-species transportability of the microsatellite markers in walnut is not yet available. PEAKALL et al. (1998) demonstrated that the successful cross-species amplification of SSRs does not prove the maintenance of the repeat motif in the non-source species. Studies employing cross-species amplification should therefore be accompanied by knowledge of the underlying DNA sequence.

This study refers to (1) the identification of new $J . x$ intermedia hybrids and the characterization of their parentage species J. regia and J. nigra in a mixed Italian population using SSR markers, (2) the detection of J. nigra genotypes with a spontaneous crossing ability with J. regia. (3) In particular, this research was designed to confirm the transferability of ten black walnut SSR loci to Persian walnut and check whether interspecific differences between alleles are due to simple changes in the number of repeats or to deletions/insertions in the flanking regions.

\section{Materials and Methods}

\section{Plant material}

In the last six years the C.N.R. Institute of Agro-environmental and Forest Biology (Porano) has been involved in a wide monitoring activity of walnut germplasm in Italy (Project RI.SEL.ITALIA.). In this framework, a mixed population, including J. nigra, $J$. regia and some putative J. nigra x J. regia hybrids, was found in Veneto region, Villa Mezzalira Park, Bressanvido (Northern Italy $45^{\circ} 39^{\prime} 0^{\prime \prime} \mathrm{N}, 1^{\circ} 38^{\prime} 0^{\prime \prime} \mathrm{E}$ ). In spring 2003, 138 total plants were sampled and the collected mature leaves were stored at $-80^{\circ} \mathrm{C}$. Preliminary morphological observations of this germplasm classified 49 individuals as J. regia, 82 genotypes as J. nigra and 7 plants as "peculiar" trees. These plants, morphologically similar to J. nigra, were the only survivors in the dense shade of the undergrowth whereas the other plants from natural regeneration couldn't reach the second year of live. For this reason, without any other information, the owner of the park arbitrary indicated the seven trees as "putative inter-specific hybrids". Sixty samples (49 J. regia from 1 to 49, 8 J. nigra labelled N3N4-N5-N17-N18-N21-N22-N23, 3 hybrids labelled H1, $\mathrm{H} 2, \mathrm{H} 19)$ were taken from adult trees growing in the Park. To have an overview as more complete is possible of the pollen cloud, we sampled also $15 \mathrm{~J}$. nigra adults located outside the garden wall. In absence of information about the origin of the J. nigra trees (they were planted during the $19^{\text {th }}$ century by the past owners of Mezzalira country house), these last were labelled "NC" just to recognize the two sub-groups. In addition leaves were picked from 63 young plants (59 J. nigra and 4 hybrids labelled IMP3, IMP4, IMP9, IMP18) grown from seeds collected in this Park in autumn 2002 and actually conserved in the Veneto regional nursery (Montecchio Precalcino, Vicenza). 


\section{DNA extraction}

Genomic DNA was extracted from leaf tissue using the Qiagen DNeasy96 Plant Kit, and stored at $-20^{\circ} \mathrm{C}$. DNA presence was monitored by subjecting sample to $1 \%$ agarose gel electrophoresis in $0.5 \times$ TBE buffer. The amount of DNA was spectrophotometrically determined and was brought to a working concentration of $5 \mathrm{ng} / \mu \mathrm{L}$.

\section{SSR analysis}

Ten microsatellite loci (WGA1, WGA4, WGA9, WGA69, WGA89, WGA118, WGA202, WGA276, WGA321, WGA331) already used for the genetic characterization of some walnut cultivars (DANGL et al., 2005) were amplified in all samples. Polymerase chain reaction (PCR) was done in $20 \mu \mathrm{L}$ of reaction volume containing $20 \mathrm{ng}$ of DNA template, $10 \mathrm{mM}$ Tris- $\mathrm{HCl}(\mathrm{pH}=$ 8.0), $50 \mathrm{mM} \mathrm{KCl,} 1.5 \mathrm{mM} \mathrm{MgCl}_{2}$ reaction buffer, $200 \mu \mathrm{M}$ dNTP (each), $0.2 \mu \mathrm{M}$ primer (both), $0.008 \mu \mathrm{g}$ BSA and $0.4 \mathrm{U}$ of Taq polymerase (Roche Applied Science). Reactions were performed in a GENEAmp 9700 Thermocycler according to the following procedure: an initial denaturation at $94^{\circ} \mathrm{C}$ for $5 \mathrm{~min}$, followed by 35 cycles of $45 \mathrm{sec}$ at $94^{\circ} \mathrm{C}, 45 \mathrm{sec}$ at the optimum annealing temperature for each couple of primes, and $1 \mathrm{~min}$ at $72^{\circ} \mathrm{C}$; then a final extension step at $72^{\circ} \mathrm{C}$ for $7 \mathrm{~min}$. The amplified fragment was checked testing $5 \mu \mathrm{L}$ aliquot of the amplified reaction by electrophoresis on $1.8 \%$ agarose gel in $0.5 \times$ TBE buffer, and stained with ethidium bromide. To determine the exact size of the amplified microsatellite fragments, samples were diluted up to 1:10 in water and $1 \mu \mathrm{L}$ of the diluted PCR product was mixed with 0.3 ( $\mathrm{L}$ of a $500 \mathrm{bp}$ internal-lane size standard (Gene Scan ${ }^{\mathrm{TM}}-500$ ROX, Applied Biosystem) and 9.7 $\mu \mathrm{L}$ of pure deionized-formamide, denatured in a thermocycler at $95^{\circ} \mathrm{C}$ for 5 minutes, and immediately chilled on ice. PCR amplification fragments were resolved by capillary electrophoresis on an ABI PRISM 3100 Genetic Analyzer (Applied Biosystem).

\section{Sequence analysis}

A J. nigra private allele and a J. regia private allele were sequenced at each locus using the corresponding forward and reverse primers. For locus WGA331, two additional alleles of different sizes were analyzed to validate the sequence variation of SSR flanking regions among Persian and black walnut. PCR reactions were performed on homozygous individuals, and the amplification products were subjected to electrophoresis in $1.8 \%$ agarose gel. The amplified fragments were directly purified with the QIAquick PCR purification Kit (Qiagen) and used as template for the sequencing reactions.
The total reaction volume of $20 \mu \mathrm{L}$ contained $1.5 \mu \mathrm{L}$ of template DNA, $2 \mu \mathrm{L}$ of $5 \mathrm{X}$ BigDye Terminator v. 1.1 Buffer, $4 \mu \mathrm{L}$ of BigDye Terminator v. 1.1 Ready Reaction Mastermix (Applied Biosystem), and $0.2 \mu \mathrm{M}$ primer. The sequencing thermal profile was $1 \mathrm{~min}$ at $96^{\circ} \mathrm{C}$, followed by 25 cycles of $96^{\circ} \mathrm{C}$ for $10 \mathrm{sec}, 50^{\circ} \mathrm{C}$ for $5 \mathrm{sec}$, and $60^{\circ} \mathrm{C}$ for $4 \mathrm{~min}$ on a GENEAmp 9700 Thermocycler. Sequencing reaction products were purified by SpinColumns kits (Princeton/Applied Biosystem) and run on the ABI PRISM 3100 Genetic Analyzer.

\section{Cytological analysis}

Developing male flowers from the selected trees were collected in a stage putatively young enough for the cytological examination. The buds were collected and immediately placed into the fixative solution (glacial acetic acid: absolute ethanol $=1: 3$ ) for 24 hours at room temperature; the fixative solution was refreshed twice. Subsequently the material was preserved in ethanol $70 \%$ and stored at $-20^{\circ} \mathrm{C}$. Developing pollen mother cells were microscopically checked after traditional aceto-carmine staining.

\section{Data analysis}

The SSR amplified fragment data were collected using Gene Scan Analysis version 3.7 Software and genotype profiles were assigned with the aid of Genotyper version 3.7 NT Software (Applied Biosystem). The Simple Match's similarity coefficient (SM- Sokal \& Sneath 1963) was calculated between all pairwise combinations of individuals in order to evaluate the genetic relationships between genotypes. The Principal Coordinate Analysis (PcoordA) based on the SM matrix displayed the relative genetic distances of the genotypes in a bidimensional plot (ROLF's 2001, NTSYSpc version 2.1 software package).

Two different measures of genetic differentiation among groups were calculated via AMOVA (ExCOFFIER et al., 1992): WRIGHT's (1951) $F_{\text {st }}$ coefficient, based on the Infinite Alleles Mutation Model of loci (IAM, KIMURA and CROW, 1964), and Slatkin's (1995) $R_{\text {st }}$ coefficient that takes into account a stepwise mutation model (SMM, KIMURA and OTHA, 1978). SMM model may reflect more accurately the mutation pattern of microsatellites. The indices of genetic diversity, number of alleles per locus $\left(\mathrm{N}_{\mathrm{a}}\right)$, effective number of alleles $\left(\mathrm{N}_{\mathrm{e}}\right)$, observed $\left(\mathrm{H}_{\mathrm{o}}\right)$ and expected $\left(\mathrm{H}_{\mathrm{E}}\right)$ heterozygosity were calculated for each locus. A Chi-square test (HEDRICK, 2000) was applied to determine whether the observed genotype frequencies were consistent with Hardy-Weinberg expectations, and a g-square test was used to test for linkage disequilibrium between SSR loci. All calcula-

Table 1. - Comparison of the genetic diversity of four Juglans populations using $F_{\mathrm{ST}}$ (WRIGHT, 1965) and $R_{\mathrm{ST}}$ (SLATKIN's, 1995) based on 10 microsatellite loci amplified in 137 diploid genotypes. $R_{\mathrm{ST}}$ and $F_{\mathrm{ST}}$ below the diagonals, the significance of test for each comparison, based on 1000 permutations, above diagonals.

\begin{tabular}{cccc|l|cccc}
\hline \multicolumn{4}{c|}{ Pairwise Population $F_{\mathrm{ST}}$ Values } & & \multicolumn{3}{c}{ Pairwise Population $R_{\mathrm{ST}}$ Values } \\
\hline J. nigra & J. nigra NC & J.regia & Hybrids $2 n$ & & J.nigra & J. nigra NC & J.regia & Hybrids $2 n$ \\
\hline- & 0.001 & 0.001 & 0.001 & J.nigra & - & 0.001 & 0.001 & 0.001 \\
0.216 & - & 0.001 & 0.001 & J. nigra NC & 0.093 & - & 0.001 & 0.001 \\
0.432 & 0.295 & - & 0.001 & J.regia & 0.958 & 0.933 & - & 0.001 \\
0.197 & 0.174 & 0.220 & - & Hybrids $2 n$ & 0.735 & 0.420 & 0.680 & - \\
\hline
\end{tabular}


tions were performed using POPGENE version 1.32 programme (YEH and BOYLE, 1997; http://www.ualberta. ca/ fyeh/index.htm) and GenAlEx version 6 software (PEAKALl and SMOUSE, 2005).

Sequences were analyzed and edited with the Sequence analyzing software 3.7 (Applied Biosystem) and aligned using the CLUSTAL W (http://www.ebi. ac.uk/clustalw/) multiple alignment package (THOMPSON et al., 1994). BLAST (blastn) queries were performed against the non-redundant (nr) Viridiplantae database (GeneBank database http://www.ncbi.nlm.nih.gov) to confirm the transferability of microsatellite loci and to assess the sequence variation of SSR flanking regions within J. nigra and between J. nigra and J. regia. Then walnut sequences were compared to the genome database of Populus tricocharpa (http://genome.jgi-psf.org/ Poptr1/Poptr1.home.html) to determine if the flanking regions of the microsatellites had significant homology with any known genes. BLAST searches were conducted using both the DNA sequence and the three possible amino-acid translations. The complete sequence of the corresponding clones available on the public NCBI database was used after filtering low complexity regions. All BLAST hits with expect value $(\mathrm{E})>1.0 \mathrm{E}-05$ were eliminated.

\section{Results}

\section{Fingerprinting analysis}

All ten microsatellites amplified in both species, producing fragments of variable sizes (Table 2). A total of 112 alleles were detected, an average of 11.2 per primer, ranging from eight in WGA69 to 20 in WGA276. The Principal Coordinate Analysis performed on the Simple Match's similarity coefficient on the basis of 112 alleles (binary code) divided the 138 total genotypes into four distinct groups (Figure 1). The first principle coordinate, which accounted for $34.23 \%$ of the variance, clearly separated the two species. The second principal coordinate, explaining $6.08 \%$ of the variance, divided the J. nigra trees in two subgroups. J. nigra-NC plants, sampled around Villa Mezzalira Park, were in a close but separate group, revealing a definite genetic distinctness from the other eastern black walnut trees planted inside the Park. The putative inter-specific hybrids (J. x intermedia) H1, H2, H19, IMP3, IMP4, IMP9 IMP18 were not included in the above three groups, but on the plot were located in intermediate position between black and common walnut. Finally, one adult tree located inside park, originally classified as J. nigra (N21), was placed between black walnut and the hybrid groups.

Table 2. - List of microsatellite alleles that are common or specific for J. nigra (joining the subgroups J. nigra and J. nigra-NC,) and $J$. regia (percentage in brackets).

\begin{tabular}{|c|c|c|c|c|}
\hline \multirow[t]{2}{*}{.Locus } & \multirow[t]{2}{*}{$\begin{array}{l}\text { Number of } \\
\text { total alleles }\end{array}$} & \multicolumn{2}{|c|}{ Private alleles (bp) } & $\begin{array}{l}\text { Common } \\
\text { alleles (bp) }\end{array}$ \\
\hline & & J. nigra & J. regia & \\
\hline WGA1 & 9 & $182-184-186-188$ & $181-193-195$ & 191 \\
\hline WGA4 & 10 & $240-242-246-248-280-252-257$ & $231-233$ & 237 \\
\hline WGA9 & 9 & $229-241-251-255-257-261$ & 239 & $243-247$ \\
\hline WGA69 & 8 & $169-171-173$ & $159-161-167$ & $175-179$ \\
\hline WGA89 & 11 & $190-196-201-203-207-213-222-230$ & $215-221$ & 211 \\
\hline WGA118 & 12 & $210-212-215-221-223-226-235-243$ & $183-196-198-206$ & - \\
\hline WGA202 & 11 & $246-248-250-252-254-258$ & $265-267-275-295$ & 260 \\
\hline WGA276 & 20 & $144-147-149-153-157-159-161-163-165-167$ & $171-173-177-179-181-183-187-189-191-195$ & - \\
\hline WGA321 & 12 & $236-237-242-244-246-254-264$ & $226-239-241-243-245$ & - \\
\hline WGA331 & 10 & $177-179-181-185-187-189-191-195$ & $270-274$ & - \\
\hline Total & 112 & $68(60.7 \%)$ & $36(32.1 \%)$ & $8(7.14 \%)$ \\
\hline
\end{tabular}

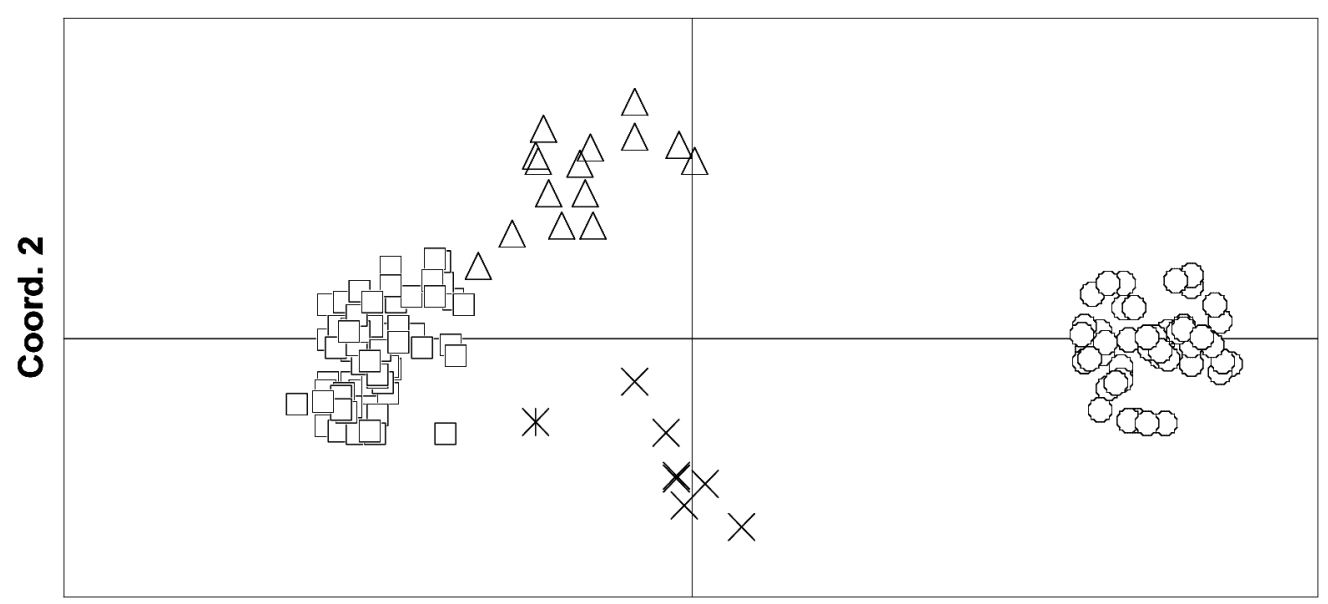

Coord. 1

Figure 1. - Principal Coordinate Analysis of 138 Juglans individuals based on the genotypic similarities (SM - simple match coefficients) of 10 SSR loci. Labels stand for sample groups: $\bigcirc$ J. regia, $\square$ J. nigra, $\triangle$ J. nigra NC, $*$ N21 genotype, and $\times$ putative hybrids (H1, H2, H19, IMP3, IMP4, IMP9 IMP18). 
The pairwise values of $F_{\text {st }}$ (WRIGHT, 1965) and $R_{\text {st }}$ (SlatKIN, 1995) indices determined by the AMOVA analysis (Table 1) reflected the genetic diversity among the groups displayed in Figure 2. The greatest inter-population distance detected was between J. nigra and J. regia $\left(R_{\mathrm{st}}=0.958 ; F_{\mathrm{st}}=0.432\right)$. The lowest genetic differentiation was measured between J. nigra and J. nigra-NC by $R_{\mathrm{st}}$ (0.093), and between J. nigra-NC and the diploid hybrid genotypes using $F_{\text {st }}(0.174)$. The AMOVA analysis attributed $90 \%$ of the molecular variance among groups and 10\% within groups using the $R_{\text {st }}$-statistic; by contrast, the Fst statistic partitioned $35 \%$ of the variation among and $65 \%$ within groups.

A detailed analysis of the 112 total alleles revealed that 8 alleles $(7.14 \%)$ were common to black and Persian walnut and were labelled as "common alleles". In addition, 104 alleles (92.86\%), 68 (60.7\%) amplifying in J. nigra and $36(32.1 \%)$ in J. regia only, were classified as species "private alleles". J. nigra had more private alleles than J. regia at nearly every locus, but these difference decrease considerably when the number of private alleles is normalized by sample size (Table 2 ). The allele frequencies for each locus (data not shown), can be provided.

The microsatellite loci revealed high level of variability in the tested samples. The number of alleles per locus $\left(\mathrm{N}_{\mathrm{a}}\right)$, effective number of alleles $\left(\mathrm{N}_{\mathrm{e}}\right)$, observed $\left(\mathrm{H}_{\mathrm{o}}\right)$ and expected $\left(\mathrm{H}_{\mathrm{E}}\right)$ heterozygosity were showed in the Table 3 . In neither species did any of the ten loci exhibit link- age disequilibrium or any significant deviation from Hardy-Weinberg equilibrium. For the loci WGA118, WGA276 and WGA331, the length of the J. nigra alleles did not overlap with the corresponding J. regia alleles, and large differences in allelic size between species were found.

The genotypic profile of the hybrids showed one J. nigra and one J. regia private allele at the loci WGA4, WGA118, WGA202, WGA276, WGA321, WGA331, whereas in three loci, WGA1, WGA9, WGA89, one or two private alleles were replaced by one or two common alleles (Table 4). This fingerprinting analysis also clarified the genetic constitution of the N21 genotypes genotype. The amplification of 1 common/J. regia and 2 common/J. nigra private alleles at 6 loci, 1 common/J. nigra and 1 common/J. regia private alleles at 3 loci indicated the triploid hybrid nature of this plant, characterised by two genome parts of J. nigra and one part of J. regia. For the primer pair WGA69, no J. regia and only one J. nigra private allele was amplified in each hybrid tree. The observed allele (range size 169-180 bp for J. nigra and 159-180 bp for J. regia) overlapped, an amplification advantage for the shorter fragments cannot explain the presence of a null allele in the hybrids. Probably the lack of the amplification was due to a mutation in the SSR flanking regions that changed the affinity of the primer pairs in the annealing sites. In addition the mother testing analysis of the diploid hybrids by exclusion method (based on Mendelian rules of inheritance)
WGA331 AY479963 WGA3 31 J.nigra WGA331 J.nigra WGA331_J.regia WGA331_J.regia

WGA331 AY479963 WGA331-J.nigra WGA331-J.nigra WGA331 J.regia WGA331_J.regia

WGA331_AY479963 WGA331 J.nigra WGA $331^{-} \mathrm{J}$.nigra WGA331_J.regia WGA 331 J.regia

WGA331 AY479963

WGA331 J.nigra WGA3 $31^{-} \mathrm{J}$.nigra WGA331 J.regia WGA331_J.regia

WGA331_AY479963 WGA331 J.nigra WGA331-J.nigra WGA331_J.regia WGA331_J.regia

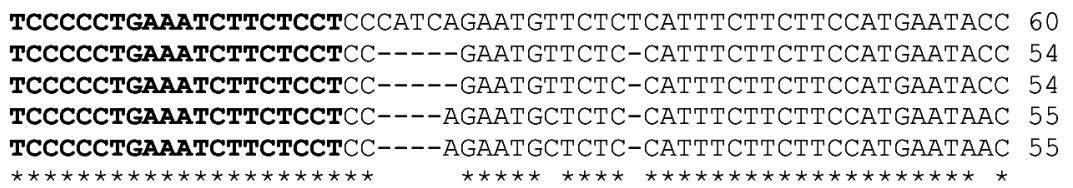

АСTTTTTACССАСССССTTTCAGTTTATTTTTCTTTTCTTCACССTCAACTTATCTTCTC 120 AСTTTTTACCCACCCCCTTTCAGTTTATTTTTCTTTTCTTCACCCTCAACTTATCTTCTC 114 ACTTTTTACCCACCCCCTTTCAGTTTATTTTTCTTTTCTTCACCCTCAACTTATCTTCTC 114 ACTTTTTACCCACCCACTT-CAGTTTATTTTTCTTTTCTTCACCCTCAAATTATCTTCTC 114 AСTTTTTACCCACCCACTT-CAGTTTATTTTTCTTTTCTTCACCCTCAAATTATCTTCTC 114

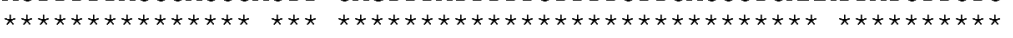

AGTAGACGTGCTCTCTCTCTCTCTCTCTCTCTCTCT-------------------- 156 AGTAGACGTGCTCTCTCTCTCTCTCTCTCTCTCTCT ------------------150

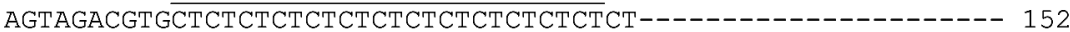
AATAGA--TGCTCTCTCTCTCTCTCTCT----------CGGTCTCTTTTTCAATTTTA 160 AATAGA--TGCTCTCTCTCTCTCTCTCTCT--------CTTGGTCTCTTTTTCAATTTTA 164

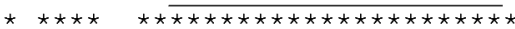

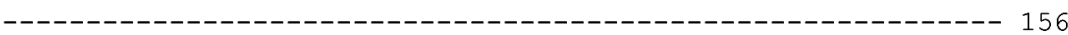

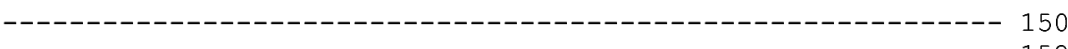

TTTTCACCTCCTTGTGTACCATACTCAACCGCTAGCCATGAGAACCACCATGCTCATACA 220 TTTTCACCTCCTTGTGTACCATACTCAACCGCTAGCCATGAGAACCACCATGCTCATACA 224

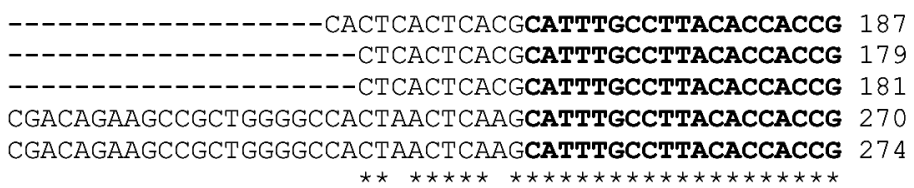

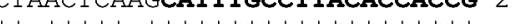

Figure 2. - CLUSTAL W alignment of two private alleles of J. nigra (179bp; 181bp), two private alleles of J. regia (270bp; 274bp) and the database sequence (GeneBank accession number AY479963) at locus WGA331. The forward and reverse primers are indicated in bold, gaps are indicated with dashes, stars indicate sequence identity. 
Table 3. - Values of genetic variability observed in two subgroups of black walnut (J. nigra and J. nigra $\mathrm{NC}$ ), J. regia species and their hybrid: Number $\left(\mathrm{N}_{\mathrm{a}}\right)$, size range and the effective number $\left(\mathrm{N}_{\mathrm{e}}\right)$ of the alleles per locus, observed $\left(\mathrm{H}_{\mathrm{o}}\right)$ and expected heterozygosity $\left(\mathrm{H}_{\mathrm{E}}\right)$.

\begin{tabular}{|c|c|c|c|c|c|c|}
\hline Source & Locus & $\mathrm{N}_{\mathrm{a}}$ & Size range $(\mathrm{bp})$ & $\mathrm{N}_{\mathrm{e}}$ & $\mathrm{H}_{\mathrm{o}}$ & $\mathrm{H}_{\mathrm{E}}$ \\
\hline \multirow{11}{*}{$\begin{array}{l}\text { Juglans nigra } \\
\qquad(\mathrm{N}=66)\end{array}$} & WGA1 & 5 & $182-191$ & 2.703 & 0.652 & 0.630 \\
\hline & WGA4 & 8 & $237-257$ & 1.834 & 0.439 & 0.455 \\
\hline & WGA9 & 6 & $229-261$ & 2.901 & 0.667 & 0.655 \\
\hline & WGA69 & 2 & $169-171$ & 1.163 & 0.152 & 0.140 \\
\hline & WGA89 & 7 & $190-213$ & 3.337 & 0.758 & 0.700 \\
\hline & WGA118 & 3 & $215-226$ & 2.297 & 0.697 & 0.565 \\
\hline & WGA202 & 5 & $248-260$ & 1.618 & 0.424 & 0.382 \\
\hline & WGA276 & 6 & $147-167$ & 1.924 & 0.500 & 0.480 \\
\hline & WGA321 & 6 & $236-264$ & 1.265 & 0.212 & 0.210 \\
\hline & WGA331 & 6 & $177-195$ & 2.921 & 0.682 & 0.658 \\
\hline & Mean (SE) & $5.4(0.56)$ & & $2.196(0.24)$ & $0.518(0.21)$ & $0.487(0.06)$ \\
\hline \multirow{11}{*}{$\begin{array}{l}\text { Juglans nigra } \mathrm{NC} \\
\quad(\mathrm{N}=15)\end{array}$} & WGA1 & 4 & $182-197$ & 1.891 & 0.533 & 0.471 \\
\hline & WGA4 & 6 & $237-252$ & 4.891 & 0.800 & 0.796 \\
\hline & WGA9 & 6 & $229-257$ & 3.435 & 0.800 & 0.709 \\
\hline & WGA69 & 4 & $171-180$ & 2.332 & 0.467 & 0.571 \\
\hline & WGA89 & 7 & $190-230$ & 3.689 & 0.800 & 0.729 \\
\hline & WGA118 & 7 & $210-243$ & 2.744 & 0.667 & 0.636 \\
\hline & WGA202 & 6 & $246-260$ & 5.625 & 0.800 & 0.822 \\
\hline & WGA276 & 8 & $144-167$ & 5.172 & 0.600 & 0.807 \\
\hline & WGA321 & 6 & $236-264$ & 5.357 & 1.000 & 0.813 \\
\hline & WGA331 & 7 & $179-195$ & 4.787 & 0.800 & 0.791 \\
\hline & $\operatorname{Mean}(S E)$ & $6.1(0.41)$ & & $3.992(0.43)$ & $0.727(0.16)$ & $0.714(0.04)$ \\
\hline \multirow{11}{*}{$\begin{array}{l}\text { Juglans regia } \\
\qquad(\mathrm{N}=49)\end{array}$} & WGA1 & 4 & $181-195$ & 2.853 & 0.612 & 0.650 \\
\hline & WGA4 & 3 & $231-237$ & 1.782 & 0.429 & 0.439 \\
\hline & WGA9 & 3 & $239-247$ & 2.441 & 0.531 & 0.590 \\
\hline & WGA69 & 5 & $159-180$ & 3.435 & 0.816 & 0.709 \\
\hline & WGA89 & 3 & $211-221$ & 2.823 & 0.653 & 0.646 \\
\hline & WGA118 & 4 & $183-206$ & 3.120 & 0.776 & 0.680 \\
\hline & WGA202 & 5 & $260-295$ & 3.482 & 0.735 & 0.713 \\
\hline & WGA276 & 10 & $171-195$ & 3.161 & 0.531 & 0.684 \\
\hline & WGA321 & 5 & $226-245$ & 3.349 & 0.633 & 0.701 \\
\hline & WGA331 & 2 & $270-274$ & 1.979 & 0.571 & 0.495 \\
\hline & $\operatorname{Mean}(S E)$ & $4.4(0.70)$ & & $2.843(0.19)$ & $0.629(0.12)$ & $0.631(0.03)$ \\
\hline \multirow{11}{*}{$\begin{array}{l}\text { Hybrid } \\
(\mathrm{N}=7)\end{array}$} & WGA1 & 5 & $181-193$ & 4.083 & 1.000 & 0.755 \\
\hline & WGA4 & 3 & $231-250$ & 2.513 & 1.000 & 0.602 \\
\hline & WGA9 & 3 & $239-247$ & 2.649 & 1.000 & 0.622 \\
\hline & WGA69 & 1 & 171 & 1.000 & 0.000 & 0.000 \\
\hline & WGA89 & 4 & $201-215$ & 2.882 & 1.000 & 0.653 \\
\hline & WGA118 & 4 & $196-226$ & 3.920 & 1.000 & 0.745 \\
\hline & WGA202 & 3 & $252-267$ & 2.513 & 1.000 & 0.602 \\
\hline & WGA276 & 3 & $147-189$ & 2.279 & 1.000 & 0.561 \\
\hline & WGA321 & 4 & $226-244$ & 2.970 & 1.000 & 0.663 \\
\hline & WGA331 & 3 & $181-274$ & 2.513 & 1.000 & 0.602 \\
\hline & Mean (SE) & $2.732(0.86)$ & & $1.021(0.40)$ & $0.900(0.31)$ & $0.581(0.21)$ \\
\hline
\end{tabular}

indicated one of the eight J. nigra trees growing in the Park, J. nigra-N17, as the only putative hybridogenic mother plant in this walnut population (Table 4).

Somatic chromosome count was carried out on pollen mother cells from hybrids, confirming the genotyping results. The number of somatic chromosomes was verified as diploid $(2 \mathrm{n}=32)$ for 7 hybrids $(\mathrm{H} 1, \mathrm{H} 2, \mathrm{H} 19$, IMP3, IMP4, IMP9 IMP18) and triploid $(3 \mathrm{n}=48)$ for N21 plant.

\section{SSR sequence comparison}

Sequence analysis was carried out to confirm the identity of the amplified fragments and to assess the sequence variation of SSR flanking regions within $J$. nigra (joining the subgroup J. nigra and J. nigra $\mathrm{NC}$ ) and between J. nigra and J. regia. In this way it was possible to explore the reasons for the large differences in the allelic size between J. nigra and J. regia observed at WGA118, WGA276, WGA331, as well as to investi- gate the presumed null allele at locus WGA69 in the hybrids.

When the priming sites, SSR flanking regions, and repeat motifs of black and common walnut were compared to the J. nigra consensus sequences available on the NCBI database using BLASTn, large interlocus differences in the number of transition and transversion events were observed (Table 5). In every case, the microsatellite repeat region was found and could be further classified into three categories: pure (WGA9, WGA202, WGA276, WGA321, WGA331) compound pure (WGA4, WGA89, WGA118) or interrupted (WGA1, WGA69). In J. regia, WGA1 contained pure (GA) repeats instead of the interrupted microsatellite found in J. nigra. In both species, the flanking regions at all ten loci displayed significant homology with the corresponding J. nigra consensus sequences from which the primers were originally derived (E -value $\leq 3 \mathrm{e}^{-27}$ ). Particularly the microsatellites WGA1, WGA4, WGA9, 
WGA69, WGA89, WGA118, WGA276 and WGA321 revealed a high percentage of sequence identity with the consensus sequences at the SSR flanking regions (from $100 \%$ to $95 \%$ for J. nigra and from $98 \%$ to $90 \%$ for J. regia). In these loci, few gaps and point mutations were observed. The differences in allele size reflected mainly variation in the repeat region.

Among the eight loci mentioned above, results for WGA1, WGA118, WGA276 and WGA69 were particularly interesting. The WGA1 locus exhibited the highest percent homology in the $155 \mathrm{bp}$ flanking regions, $100 \%$ for J. nigra with no gaps or base mutations, and $98 \%$ for J. regia, with gaps $(1.27 \%)$ and point mutations $(1.27 \%)$. At this locus the interrupted microsatellite, $(\mathrm{GA})_{5} \mathrm{GCA}(\mathrm{GA})_{3} \mathrm{GCA}(\mathrm{GA})_{3}$ of the J. nigra consensus sequences (Table 5) changed, becoming (GA) ${ }_{15} \mathrm{G}(\mathrm{GA})$ in the J. nigra private-allele 188 (bp), and a pure microsatellite $(\mathrm{GA})_{12}$ in the $181 \mathrm{bp}$ private allele of J. regia. Although the SSR flanking regions were highly conserved, wide differences in allele size between $J$. regia and J. nigra were found at WGA118 and WGA276 (Table 5). The difference in length between $J$. regia $189 \mathrm{bp}$ and J. nigra $153 \mathrm{bp}$ alleles at the WGA276 locus was probably due to a large contraction of the repeat region, with the loss of 16 (GA) units. On the other hand, expansion of the repeat region by the addition of nine (GA) and 17 (GT) units occurred at the WGA118 locus, giving rise to the $226 \mathrm{bp}$ allele in $J$. nigra, instead of the $196 \mathrm{bp}$ allele observed in $J$. regia. The alleles of identical size (180 bp) that amplified in black and common walnut at the WGA69 locus showed different percent homology in the flanking regions (97\% and $90 \%$ respectively), and several mutations in the corresponding interrupted microsatellite. In the $J$. regia sequence of WGA69 a short indel of $3 \mathrm{bp}$ was observed $5 \mathrm{bp}$ downstream of the forward primer. This result cannot explain the absence of a J. regia allele at locus WGA69 in the hybrids (Table 2). A dis-

Table 4. - SSR genotypes for seven diploid hybrid one triploid hybrid plant and one J. nigra hybridogenic plant. Allele length in base pairs (bp), - marks stand for null allele. Shading: $50 \%$ grey for J. nigra-private alleles, $25 \%$ grey for J. regia-private alleles, unshaded cells for common alleles.

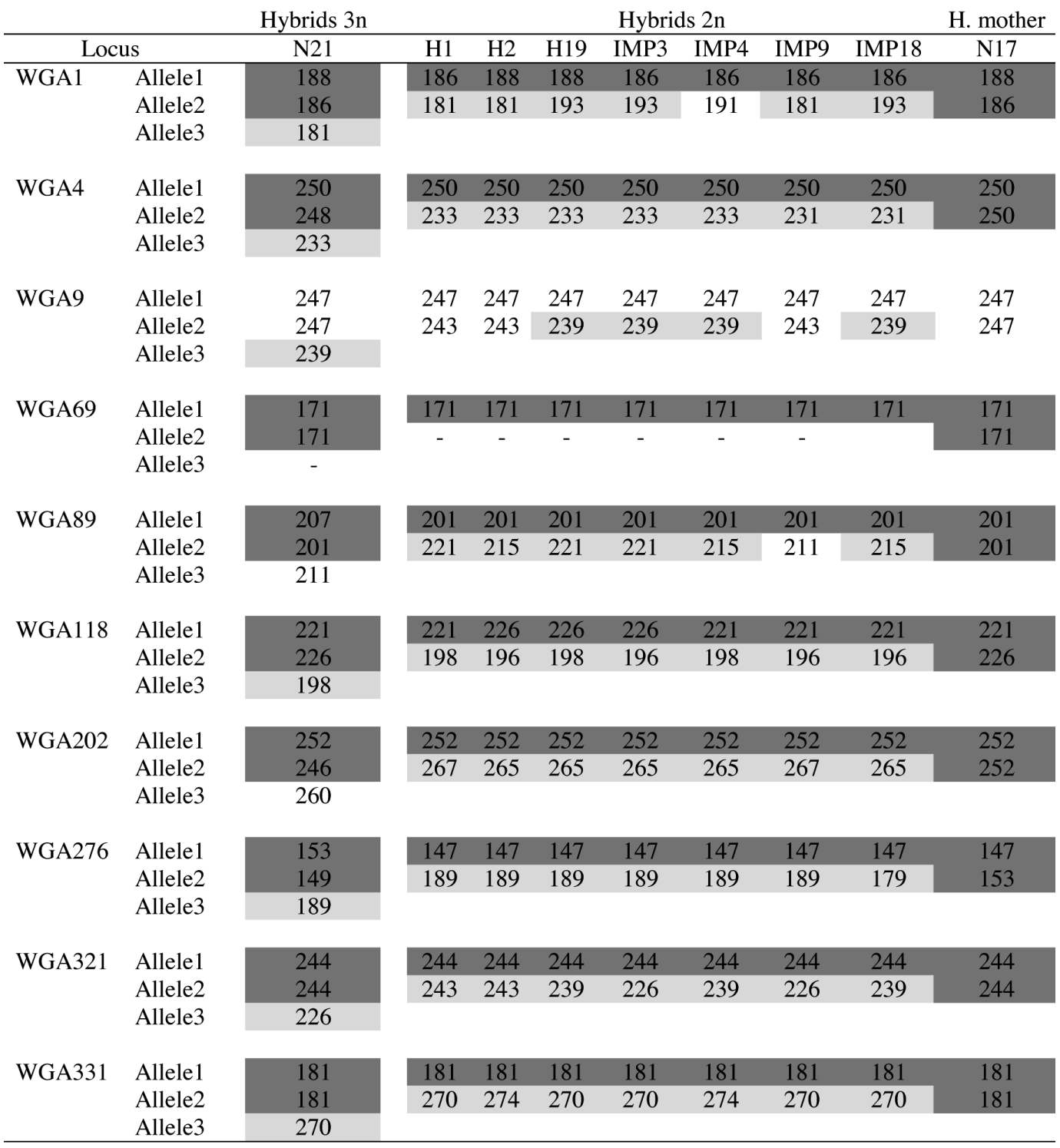


Table 5. - Summary of sequence analysis of 10 microsatellite loci in the studied samples belonging to J. nigra and J. regia species. Comparison with J. nigra consensus sequence for the SSR flanking regions available on public NCBI database (BLASTn; WoESTE et al., 2002).

\begin{tabular}{|c|c|c|c|c|c|c|c|c|c|c|}
\hline \multirow{3}{*}{ Locus SSR } & \multirow{3}{*}{$\begin{array}{l}\text { Allele } \\
\text { Size } \\
\text { (bp) }\end{array}$} & \multirow{3}{*}{$\begin{array}{c}\text { GeneBank } \\
\text { Accession } \\
\text { Number }\end{array}$} & \multirow{3}{*}{$\mathrm{N}^{\circ}$ of $(\mathrm{AG})$ repeats } & \multirow{3}{*}{$\begin{array}{l}J . \text { nigra consensus sequence } \\
\mathrm{N}^{\circ} \text { of }(\mathrm{AG}) \text { repeats }\end{array}$} & \multicolumn{6}{|c|}{ BLASTn-Search for SSR flanking regions } \\
\hline & & & & & \multirow[b]{2}{*}{$\begin{array}{l}\text { GeneBank } \\
\text { A. number }\end{array}$} & \multirow[b]{2}{*}{ E-value } & \multirow[b]{2}{*}{$\begin{array}{c}\% \\
\text { homology }\end{array}$} & \multirow[b]{2}{*}{$\begin{array}{l}\% \\
\text { gaps }\end{array}$} & \multicolumn{2}{|c|}{ Point mutations } \\
\hline & & & & & & & & & $\begin{array}{c}\% \\
\operatorname{trans}^{\mathrm{a}}\end{array}$ & $\begin{array}{c}\% \\
\text { transv }^{2}\end{array}$ \\
\hline $\begin{array}{l}\text { WGA1-J.nigra } \\
\text { WGA1-J.regia }\end{array}$ & $\begin{array}{l}188 \\
181\end{array}$ & $\begin{array}{l}\text { EF640283 } \\
\text { EF640294 }\end{array}$ & $\begin{array}{c}(\mathrm{GA})_{15} \mathrm{G}(\mathrm{GA}) \\
(\mathrm{GA})_{12}\end{array}$ & $(\mathrm{GA})_{5} \mathrm{GCA}(\mathrm{GA})_{3} \mathrm{GCA}(\mathrm{GA})_{3}$ & $\underline{\mathrm{AY}} 465952$ & $\begin{array}{l}1 \mathrm{e}-68 \\
1 \mathrm{e}-62\end{array}$ & $\begin{array}{c}100 \\
98\end{array}$ & $\begin{array}{c}0 \\
1.27\end{array}$ & $\begin{array}{c}0 \\
0.63\end{array}$ & $\begin{array}{c}0 \\
0.63\end{array}$ \\
\hline $\begin{array}{l}\text { WGA4-J.nigra } \\
\text { WGA4-J.regia }\end{array}$ & $\begin{array}{l}250 \\
231\end{array}$ & $\begin{array}{l}\text { EF640284 } \\
\text { EF640295 }\end{array}$ & $\begin{array}{l}(\mathrm{GT})_{5}(\mathrm{GA})_{17},(\mathrm{GA})_{11} \\
(\mathrm{GT})_{5}(\mathrm{GA})_{10},(\mathrm{GA})_{10}\end{array}$ & $(\mathrm{GT})_{5}(\mathrm{GA})_{15},(\mathrm{GA})_{11}$ & $\underline{\mathrm{AY} 465953}$ & $\begin{array}{l}1 \mathrm{e}-41 \\
3 e-51\end{array}$ & $\begin{array}{l}95 \\
95\end{array}$ & $\begin{array}{l}3 \\
2\end{array}$ & $\begin{array}{l}1 \\
2\end{array}$ & $\begin{array}{l}1 \\
1\end{array}$ \\
\hline $\begin{array}{l}\text { WGA9-J.nigra } \\
\text { WGA9-J.regia }\end{array}$ & $\begin{array}{l}229 \\
239\end{array}$ & $\begin{array}{l}\text { EF640285 } \\
\text { EF640296 }\end{array}$ & $\begin{array}{l}(\mathrm{GA})_{7} \\
(\mathrm{GA})_{12}\end{array}$ & $(\mathrm{GA})_{16}$ & $\underline{\mathrm{AY}} 465954$ & $\begin{array}{l}1 \mathrm{e}-75 \\
1 \mathrm{e}-53\end{array}$ & $\begin{array}{l}99 \\
95\end{array}$ & $\begin{array}{l}0 \\
2\end{array}$ & $\begin{array}{c}1 \\
0.5\end{array}$ & $\begin{array}{c}0 \\
2.5\end{array}$ \\
\hline $\begin{array}{l}\text { WGA69-J.nigra } \\
\text { WGA69-J.regia }\end{array}$ & $\begin{array}{l}180 \\
180\end{array}$ & $\begin{array}{l}\text { EF640286 } \\
\text { EF640297 }\end{array}$ & $\begin{array}{c}\left.(\mathrm{GA})_{4} \mathrm{ATATAA} \mathrm{GA}\right)_{15} \\
(\mathrm{GA})_{4} \text { ATATAAGC }(\mathrm{GA})_{2} \mathrm{GC}(\mathrm{GA})_{13}\end{array}$ & $(\mathrm{GA})_{4} \mathrm{ATATAA}(\mathrm{GA})_{16}$ & $\underline{\mathrm{AY} 333953}$ & $\begin{array}{l}1 \mathrm{e}-47 \\
3 \mathrm{e}-29\end{array}$ & $\begin{array}{l}97 \\
90\end{array}$ & $\begin{array}{l}0 \\
3\end{array}$ & $\begin{array}{c}3 \\
5.5\end{array}$ & $\begin{array}{c}0 \\
0.5\end{array}$ \\
\hline $\begin{array}{l}\text { WGA89-J.nigra } \\
\text { WGA89-J.regia }\end{array}$ & $\begin{array}{l}201 \\
215\end{array}$ & $\begin{array}{l}\text { EF640287 } \\
\text { EF640298 }\end{array}$ & $\begin{array}{l}(\mathrm{GT})_{12,},(\mathrm{GA})_{13} \\
(\mathrm{GT})_{20},(\mathrm{GA})_{13}\end{array}$ & $(\mathrm{GT})_{13}(\mathrm{GA})_{21}$ & $\underline{\mathrm{AY} 352440}$ & $\begin{array}{l}1 \mathrm{e}-47 \\
1 \mathrm{e}-62\end{array}$ & $\begin{array}{l}97 \\
97\end{array}$ & $\begin{array}{c}0 \\
0.06\end{array}$ & $\begin{array}{c}1.35 \\
1.5\end{array}$ & $\begin{array}{l}1.65 \\
0.5\end{array}$ \\
\hline $\begin{array}{l}\text { WGA118-J.nigra } \\
\text { WGA118-J.regia }\end{array}$ & $\begin{array}{l}226 \\
196\end{array}$ & $\begin{array}{l}\text { EF640288 } \\
\text { EF640299 }\end{array}$ & $\begin{array}{c}(\mathrm{GA})_{23}(\mathrm{GT})_{18} \\
(\mathrm{GA})_{14}(\mathrm{GT})_{1}\end{array}$ & $(\mathrm{GA})_{18}(\mathrm{GT})_{11}$ & $\underline{\mathrm{AY} 479958}$ & $\begin{array}{l}4 \mathrm{e}-63 \\
3 \mathrm{e}-66\end{array}$ & $\begin{array}{l}98 \\
97\end{array}$ & $\begin{array}{c}0 \\
1.2\end{array}$ & $\begin{array}{c}1 \\
1.2\end{array}$ & $\begin{array}{c}1 \\
0.6\end{array}$ \\
\hline $\begin{array}{l}\text { WGA202-J.nigra } \\
\text { WGA202-J.regia }\end{array}$ & $\begin{array}{l}252 \\
265\end{array}$ & $\begin{array}{l}\text { EF640289 } \\
\text { EF640300 }\end{array}$ & $\begin{array}{l}(\mathrm{GA})_{11} \\
(\mathrm{GA})_{18}\end{array}$ & $(\mathrm{GA})_{20}$ & $\underline{\mathrm{AY} 479959}$ & $\begin{array}{l}2 \mathrm{e}-34 \\
2 \mathrm{e}-28\end{array}$ & $\begin{array}{l}69 \\
68\end{array}$ & $\begin{array}{l}17 \\
17\end{array}$ & $\begin{array}{l}9.5 \\
10\end{array}$ & $\begin{array}{c}4.5 \\
5\end{array}$ \\
\hline $\begin{array}{l}\text { WGA276-J.nigra } \\
\text { WGA276-J.regia }\end{array}$ & $\begin{array}{l}153 \\
189\end{array}$ & $\begin{array}{l}\text { EF640290 } \\
\text { EF640301 }\end{array}$ & $\begin{array}{l}(\mathrm{GA})_{14} \\
(\mathrm{GA})_{30}\end{array}$ & $(\mathrm{GA})_{14}$ & $\underline{\text { AY479961 }}$ & $\begin{array}{l}7 e-36 \\
3 e-32\end{array}$ & $\begin{array}{l}95 \\
94\end{array}$ & $\begin{array}{c}2.5 \\
2\end{array}$ & $\begin{array}{l}2.5 \\
2.5\end{array}$ & $\begin{array}{c}0 \\
1.5\end{array}$ \\
\hline $\begin{array}{l}\text { WGA321-J.nigra } \\
\text { WGA321-J.regia }\end{array}$ & $\begin{array}{l}244 \\
230\end{array}$ & $\begin{array}{l}\text { EF640291 } \\
\text { EF640302 }\end{array}$ & $\begin{array}{l}(\mathrm{GA})_{18} \\
(\mathrm{GA})_{15}\end{array}$ & $(\mathrm{GA})_{14}$ & $\underline{\text { AY479962 }}$ & $\begin{array}{l}5 e-72 \\
2 e-43\end{array}$ & $\begin{array}{l}100 \\
92\end{array}$ & $\begin{array}{c}0 \\
4.8\end{array}$ & $\begin{array}{c}0 \\
0.5\end{array}$ & $\begin{array}{c}0 \\
2.7\end{array}$ \\
\hline $\begin{array}{l}\text { WGA331-J.nigra } \\
\text { WGA331-J.nigra } \\
\text { WGA331-J.regia } \\
\text { WGA331-J.regia }\end{array}$ & $\begin{array}{l}179 \\
181 \\
270 \\
274\end{array}$ & $\begin{array}{l}\text { EF640292 } \\
\text { EF640293 } \\
\text { EF640303 } \\
\text { EF640304 }\end{array}$ & $\begin{array}{l}(\mathrm{GA})_{13} \\
(\mathrm{GA})_{14} \\
(\mathrm{GA})_{9} \\
(\mathrm{GA})_{10}\end{array}$ & $(\mathrm{GA})_{13}$ & $\underline{\mathrm{AY} 479963}$ & $\begin{array}{l}2 \mathrm{e}-45 \\
1 \mathrm{e}-50 \\
3 \mathrm{e}-27 \\
4 \mathrm{e}-50\end{array}$ & $\begin{array}{l}95 \\
95 \\
55 \\
55\end{array}$ & $\begin{array}{c}5 \\
5 \\
42 \\
42 \\
\end{array}$ & $\begin{array}{l}0 \\
0 \\
1 \\
1\end{array}$ & $\begin{array}{l}0 \\
0 \\
2 \\
2\end{array}$ \\
\hline
\end{tabular}

${ }^{\mathrm{a}}$ Number of transition mutations, ${ }^{\mathrm{b}}$ Number of transversion mutations.

tinct mutation in the annealing site of the primer may have taken place. This hypothesis could be verified only by cloning and then sequencing WGA69 from J. regia.

Despite the conservation of primer sequences, WGA202 and WGA331 showed the lowest sequence identities in the flanking regions. At the WGA202 locus, a substantial sequence diversity, not only among species (homology $=68 \%$ ) but also within $J$. nigra genotypes (homology $=69 \%$ ), was observed. In both species an indel of $37 \mathrm{bp}$ was found 38 nucleotides downstream of the forward primer when compared with the expected product. There was $95 \%$ homology between the flanking region of our J. nigra and J. regia samples. At the WGA331 locus, J. regia alleles displayed the lowest sequence identity $(55 \%)$ in comparison with J. nigra. The multiple sequence alignment generated by crossspecies amplification of the WGA331 locus showed the complex nature of polymorphism at some microsatellite loci (Figure 2). Locus WGA331 had alleles of 179 bp and
$181 \mathrm{bp}$ in black walnut and $270 \mathrm{bp}$ and $274 \mathrm{bp}$ in common walnut. A large insertion of $100 \mathrm{bp}$ was detected in the J. regia alleles between the pure (AG) microsatellite and the reverse primer; the SSR region was actually shorter than in J. nigra. We further determined that WGA331 has a putatively paralogous locus, WGA24, which is one of the thirty microsatellites identified in J. nigra by WOESTE et al. (2002) but not tested in this study. A subset of samples from both species was amplified using the WGA24 primer pair (data not showed). Analysis of the sequence variation for WGA24 locus revealed high levels of homology (87\%) between J. nigra and J. regia. Surprisingly, the sequence of WGA331 and WGA24 showed $70 \%$ similarity at the SSR flanking regions in J. regia and 54\% homology in J. nigra.

In light of the high level of conservation at the SSR flanking regions between the two species, BLASTsearches for nucleotide similarity were performed. Among others, the genome database of Populus tri-

Table 6. - Summary of BLASTn similarity searches between the flanking regions of three microsatellites highly conserved in J. regia, J. nigra, and Populus tricocharpa (http://genome.jgi-psf.org/Poptr1/Poptr1.home.html).

\begin{tabular}{|c|c|c|c|c|c|c|c|c|c|}
\hline \multirow[b]{2}{*}{$\begin{array}{l}\text { Sequence } \\
\text { ID }\end{array}$} & \multirow[b]{2}{*}{$\begin{array}{l}\text { Size } \\
\text { (bp) }\end{array}$} & \multicolumn{4}{|c|}{ BLASTn - Search vs. Populus tricocharpa database } & \multirow[b]{2}{*}{ Gene } & \multicolumn{3}{|c|}{ Match description } \\
\hline & & $\begin{array}{l}\text { Alignment } \\
\text { Length (bp) }\end{array}$ & E-value & $\begin{array}{c}\% \\
\text { Identity }\end{array}$ & Map Location & & Putative Function & Location 1 & MS2 \\
\hline $\begin{array}{c}\text { AY465952 } \\
\text { (WGA1) }\end{array}$ & 487 & 35 & $1 e-7$ & 98 & $\begin{array}{c}\text { LG_VIII } \\
15395426: 15395460\end{array}$ & Fgenesh1_pg_C_LG_VIII001943 & Haem peroxidase & $\begin{array}{c}\text { E Secretory } \\
\text { peroxisade domain }\end{array}$ & - \\
\hline $\begin{array}{l}\text { AY465953 } \\
\text { (WGA4) }\end{array}$ & 484 & 35 & $1 \mathrm{e}-15$ & 100 & LG_I 7467113:7467167 & - & - & INTG & + \\
\hline $\begin{array}{l}\text { AY479958 } \\
\text { (WGA118) }\end{array}$ & 500 & 125 & $1.9 \mathrm{e}-19$ & 91.1 & LG_XII 345718:345842 & Eugene 3.00120042 & $\begin{array}{l}- \\
\text { Transcription factor } \\
\text { ZF-HD protein } \\
\text { dimerisation region }\end{array}$ & $\begin{array}{c}\text { INTG } \\
\text { E } \\
\text { ZF-HD homeobox } \\
\text { protein Cys/His-rich } \\
\text { dimerisation region }\end{array}$ & - \\
\hline
\end{tabular}

${ }^{1}$ Location of sequences highly similar to the microsatellite flanking regions as determined by BLAST search-poplar database. $\mathrm{E}$, exon; INTG, intragenic region. ${ }^{2}$ Indicates conservation of microsatellite repeat between walnut and poplar.) 
chocarpa (http://genome.jgi-psf.org/Poptr1/Poptr1.home. $\underline{\mathrm{html}}$ ) was employed to determine whether these regions had significant homology with any genes. The BLASTsearch results based on the full-length sequences from which the primer pairs were designed revealed that the flanking region of two of the ten microsatellites showed significant similarity with a known gene of California poplar (Table 6). Upstream (215 bp) of the forward primer the WGA1 sequence (AY465952) we found a short (35 bp) stretch of high nucleotide identity (98\%) to Haem peroxidase. Using the translated amino-acid sequence, we detected a region of $76.92 \%$ homology $\left(\mathrm{E}=3 \mathrm{e}^{-08}\right)$ corresponding to a longer stretch of $78 \mathrm{bp}$ located in poplar at position LG VIII:1539540115395478. This segment of sequence, which included the 35 bp stretch described above, corresponded to the secretory peroxidase domain of the class III plant hemedependent peroxidase superfamily. A 125 nucleotide stretch of the J. nigra WGA118 sequence (AY479958), immediately preceding the SSR region, matched a Transcription factor ZF-HD protein dimerisation region, with $83 \%$ nucleotide homology $\left(\mathrm{E}\right.$-value $\left.=1.9 \mathrm{e}^{-19}\right)$. By comparing the translated amino-acid sequence of the fragment, an identity of $90 \%$ was detected $\left(\mathrm{E}\right.$ value $=7 \mathrm{e}^{-22}$ ). This part of the sequence encoded a ZF-HD homeobox protein Cys/His-rich dimerisation region.

\section{Discussion}

All ten primer pairs isolated from J. nigra also amplified microsatellites in J. regia. In this study the tested microsatellite markers, because of their high variability, exhibited a strong ability to discriminate walnut species and interspecific hybrids, in this case, J. x intermedia and to identify some putative J. nigra genotypes with a spontaneous crossing ability with J. regia (hybridogenic mother N17). They can also be used to verify the ploidy of hybrids as N21 genotype and for the alignment of a common Juglans genetic map. By the use of morphology the identification of the hybrids was not so easy. In general, traits as bark colour and ruggedness, shape of leaves, apical dominance, are not universally valid and any way appear only in adult trees. In our case both J. nigra plants and hybrids presented the same above characters. The N21 plant, in particular, appeared as a pure J. nigra and only the SSR analysis discovered its triploid nature. In addition, the microsatellite displayed high levels of genetic diversity both within J. nigra and between the species. A low level of ascertainment bias was observed; the average number of alleles per locus was higher for black walnut than for Persian walnut, an expected result for microsatellites discovered in one species but applied in non-source species. The mean number of alleles per locus and the effective number of alleles in each group were higher than the levels of variability detected in black and Persian walnut using other molecular markers such as allozymes (ForNARI et al., 1999) RFLP (FJELLSTROM and PARFITT, 1994) and RAPDs (MALVOLTI et al., 1997). The range of allelic richness and observed heterozygosity across the SSR loci was similar to the values reported for other domesticated tree species, black poplar (VAN DER SCHOOT et al., 2000), and Castanea sativa (MARINONI et al., 2003).
To determine the purity of our parental species, we compared the detected genetic variability with the results obtained on J. nigra natural populations (VICTORY et al., 2006), J. regia cultivars (DANGL et al., 2005) and varieties (Foroni et al., 2005). Moreover, preliminary unpublished data still in progress, obtained by the application of the same SSR primers set on natural and naturalised J. regia populations collected in France, Italy, Hungary, Greece, Caucasus, 3 Chinese Regions and Cile, were also considered. As expected, the genetic diversity detected in this study for J. nigra was lower than values obtained using twelve SSR loci in 43 indigenous populations of the same species (VICTORY et al., 2006), whereas it was representative of the genetic diversity observed in $J$. regia germplasm.

In black walnut, ROBICHAUD et al. (2006) demonstrated that the high levels of allelic richness and observed heterozygosity reduce the probability of pairwise genetic identity and increase the exclusion probability in the parentage analysis. These features make these markers an excellent tool for fingerprinting and parentage analysis not only in black walnut but also in Persian walnut.

A focal point of this study was the confirmation of the cross-species amplification of ten nuclear microsatellites within Juglans germplasm by sequence analysis. The results presented here demonstrate not only the conservation of the flanking regions of the microsatellites, but the microsatellites as well. This is a pre-requisite for using SSRs as markers in the non-source species J. regia. The DNA sequence analysis revealed high homology (90\%) at the SSR flanking regions of the tested loci between walnut species. These data confirmed that the detected fragments were really alleles of one locus and not of closely related loci, although the observed changes in the microsatellites were sometimes more complex than changes in the number of repeat units. Interruption of the dinucleotide repeat by indels and base substitutions was observed in loci WGA1 and WGA69. The WGA69 locus exhibited the lowest total number of alleles per locus and the highest percentage of common alleles between species $(25 \%)$. Several studies report that the interruption of perfect microsatellites is related to DNA stability in the region (TAYLOR et al., 1999; DAVIERWALA et al., 2000). These authors suggest that the purity of a repeat region influences the mutation rate and, consequently, the levels of polymorphism in SSR loci. Interrupted microsatellite repeats appear to have lower mutation rates than perfect repeats. This could explain the low level of polymorphism found at WGA69 in walnut. It was also interesting that the number of effective alleles of WGA1 in J. nigra was lower than that observed in J. regia. At this locus the interrupted microsatellite region of J. nigra was a pure repeat in J. regia. Microsatellite mutation rate may be affected by the nature of the flanking sequences, by the position of a microsatellite in the chromosome, and by "self-accelerating" (MORGANTE et al., 2002).

The analysis of the DNA sequences carried out in this study also proved that mutation at the SSR loci was not restricted to hypervariable regions. Insertion and deletion events in the flanking regions contributed to the 
variation in allelic size among and within Juglans species. Relatively low identity at the flanking regions (55\%) was found at WGA331 when J. nigra and J. regia private alleles were compared. We detected the presence of two putative paralogous loci WGA331 and WGA24. We conclude that WGA331 and WGA24 might be the result of a duplication event that evolved differently in the two species. The deletion of $100 \mathrm{bp}$ at WGA331 occurred in J. nigra only. This deletion reduced within black walnut the percentage of identity between WGA24 and WGA331 and was responsible for the low homology at WGA331 between black and common walnut.

Size homoplasy was observed at WGA69, in which alleles from J. nigra and J. regia had the same size (180 bp) but different underlying sequences. Complex mutational processes and the possibility of size homoplasy complicate the interpretation of the SSR variation and bias the interpretation of $F_{\mathrm{ST}}$ and $R_{\mathrm{ST}}$ estimates of genetic differentiation among populations. $F_{\mathrm{ST}}$ and $R_{\mathrm{ST}}$ coefficients are based on two extreme mutation models. $F_{\text {ST }}$ is calculated assuming the Infinite Alleles Mutation Model of loci (IAM, KIMURA and Crow, 1964) that does not allow for homoplasy. $R_{\mathrm{ST}}$ is computed using the sum of squared number of repeat differences and is based on Stepwise Mutation Model (SMM, KIMURA and ОTHA, 1978). Although more realistic mutation models could be developed, SMM seems to reflect more accurately the mutational mechanism of microsatellites than IAM. We believe the $R_{\mathrm{ST}}$ coefficient better estimated genetic differentiation between black and common walnut, as was reported in several studies (BALLOUX and LUGONMoulin, 2002). In the case of these two Juglans species, the SMM model appears to overstate their level of genetic differentiation $\left(R_{\mathrm{st}}=0.958\right)$ because sequence analysis proved that large indels (e.g., WGA331) occurred in the SSR flanking region. According to ANGER and BERNATCHEZ (1997), strong biases in the extent of divergence among populations are likely to be generated using $R_{\mathrm{ST}}$ when large indels in SSR flanking regions are misinterpreted as size differences in the SSR motif. In practice, the best measure to use is far from clear, and the interpretation of data should be made very cautiously. For all these reason we reported results using $F_{\mathrm{ST}}$ and $R_{\mathrm{ST}}$.

The usefulness and inter-specific transferability of microsatellites depends not only on their level of conservation but also on their origin and their dispersion in the genome. MoRgante and et al. (2002) observed that dinucleotide microsatellite have been found in the noncoding portion of the genome as well as in translated (exons) and untranslated regions of genes (introns, 5'and 3'-UTR). Genic SSRs derived from ESTs (Expressed Sequence Tags) are expected to possess high inter-specific transferability, as they belong to relatively conserved genic regions. In this study, two of eight SSR loci exhibited a high level of conservation in the flanking region within Juglans and even matched a locus in Populus trichocarpa. Specifically, WGA1 and WGA118 showed significant similarity with Haem peroxidase, highly conserved in plants, and a transcription factor ZF-HD protein dimerisation region.
In conclusion the success of cross-species SSR amplification can be increased by using EST databases as a source of SSR markers (Genic SSRs). These markers, which are likely to become more available as the cost of sequencing falls, together with anonymous SSRs derived from enriched genomic DNA libraries, are increasingly important tools for genetic studies in walnut.

\section{Acknowledgements}

The study was developed in the framework of the Italian Project "RI.SEL.ITALIA" financially supported by the Italian Ministry of Agricultural Policy (MiPAF), Sottoprogetto 1.1 "Biodiversità e Produzione di Materiale Forestale di Propagazione", coordinator Dr. FUlvio DUCCI (CRA-Arezzo). The authors thanks Dr. SusAnNA BARTOLI for her support in laboratory analysis, Dr. ClAUDiA MATTIONI for sequencing assistance. A warm thank goes to colleague and friend Dr. Gabriel E. Hemery, Director of "Forestry Horizon" Enterprise for the critical review of the manuscript.

\section{References}

Anger, B. and L. Bernatchez (1997): Complex evolution of a salmonid microsatellite locus and its consequences in inferring allelic divergence from size information. Molecular Biology and Evolution 14: 230-238.

BALloux, F. and N. LugON-Moulin (2002): The estimation of population differentiation with microsatellite markers. Molecular Ecology 11: 155-165.

DANGL, G. S., K. Woeste, M. K. Ardhya, A. Koehmstedt and C. Simon (2005): Characterization of 14 microsatellite markers for genetic analysis and cultivar identification of walnut. Journal of the American Society for Horticultural Science 130: 348-354.

Excoffier, L., P. E. SMouse and J. M. QuATtro (1992): Analysis of molecular variance from metric distances among DNA haplotypes: application to human mitochondrial DNA restriction data. Genetics 131: 479-491.

Fady, B., F. Ducci, N. Aleta, J. Becquey, R. Diaz VAZqueZ, F. FERnANDEZ LOPEZ and C. JAY-Allemand (2003): Walnut demonstrates strong genetic variability for adaptive and wood quality traits in a network of juvenile field tests across Europe. New Forests 25: 211-225.

Fjellstrom, R. G. and D. E. PARfitT (1994): Walnut (Juglans spp) genetic diversity determined by restriction-fragment length polymorphisms. Genome 37: 690-700.

Fenaroli, L. and G. Gambit (1976): Alberi. Dendroflora italica. Museo trentino di scienze naturali. Trento.

Fornari, B., F. Cannata, M. Spada and M. E. Malvolti (1999): Allozyme analysis of genetic diversity and differentiation in European and Asiatic walnut (Juglans regia L.) populations. Forest Genetics 6: 115-127.

Foroni, I., R. RaO, K. Woeste and M. Gallitelli (2005): Characterization of Juglans regia L. with SSR markers and evaluation of genetic relationships among cultivars and the 'Sorrento' landrace. Journal of Horticultural Science and Biotechnology 80: 49-53.

HeDrick, P. W. (2000): Genetics of populations. Second edition. Edited by JONES and BARTLETT (eds), Boston.

HussendORFER, E. (1999): Identification of natural hybrids Juglans x intermedia Carr. - using isoenzyme gene markers. Silvae Genetica 48: 50-52. 
Jay Allemand, C., J. Dufour and E. Germain (1990): Détection précoce et rapide des noyers hybrides interspécifiques (Juglans nigra x Juglans regia) au moyen de critères morphologiques. Revue Horticole 311: 39-41.

KImURA, M. and T. ОтнA (1978): Stepwise mutation model and distribution of allelic frequencies in finite populations. Proceedings National Academy of Sciences USA 75: $2868-2872$.

LuZA, J. G., V. S. Polito and S. A. Weinbaum (1987). Staminate bloom date and temperature responses of pollen germination and tube growth in two walnut (Juglans) species. American Journal of Botany 74: 1898-1903.

Marinoni, D., A. AkKaK, G. Bounous, K. J. Edwards and R. BотTA (2003): Development and characterization of microsatellite markers in Castanea sativa (Mill.). Molecular Breeding 11: 127-136.

McGranahan, G. H. and C. Leslie (1991): Walnuts (Juglans) In: Moore, J. N. and Ballington, J. R. (eds), Genetic Resources of Temperate Fruit and Nut Crops. Florence Italy, August 1990. ISHS Acta Horticulturae 290: 907-974.

Morgante, M., M. Hanafey and W. Powell (2002): Microsatellites are preferentially associated with nonrepetitive DNA in plant genomes. Nature Genetics 30: 194-200.

Nandakumar, N., A. K. Singh, R. K. Sharma, T. MohaPATRA, K. V. PRABHU and F. U. ZAMAN (2004): Molecular fingerprinting of hybrids and assessment of genetic purity of hybrid seeds in rice using microsatellite markers. Euphytica 136: 257-264.

Peakall, R. and P. E. Smouse (2005): GenAlEx V6: Genetic Analysis in Excel. Population genetic software for teaching and research. The Australian National University, Canberra, Australia. http://www.anu.edu.au/BoZo/ genAlEx/.

Peakall, R., S. Gilmore, W. Keys, M. Morgante and A. RAFALSKI (1998): Cross-species amplification of Soybean (Glycine max) simple-sequence-repeats (SSRs) within the genus and other legume genera: implications for the transferability of SSRs in plants. Molecular Biology and Evolution 15: 1275-1287.

Pollegioni, P., A. Major, S. Bartoli, F. Ducci, R. ProietTI and M. E. MALVOLTI (2006): Application of microsatellite and dominant molecular markers for the discrimination of species and interspecific hybrids in genus
Juglans. Sorrento, Italy, November 2004. ISHS Acta Horticulturae 705: 191-197.

Robichaud, R. L., J. C. Glaubitz, O. E. JR Rhodes and K. Woeste (2006): A robust set of black walnut microsatellites for parentage and clonal identification. New Forest 32: 179-196.

RoHLF, F. J. (2001): NTSYS-pc. Numerical Taxonomy and Multivariate Analysis System. Version 2.1. Exeter Software. East Setauket, New York.

SLATKIN, M. (1995): A measure of population subdivision based on microsatellite allele frequencies. Genetics 139: 457-462.

SokAL, R. R. and P. H. A. SNEATH (1963): Principles of numerical taxonomy. Freeman, San Francisco.

Stanford, A. M., R. HARden and C. R. PARKs (2000): Phylogeny and biogeography of Juglans (Juglandaceae) based on matK and ITS sequence data. American Journal of Botany 87: 872-882.

Streiff, R., A. Ducousso, C. Lexer, H. Steinkellner, J. Gloessl and A. Kremer (1999): Pollen dispersal inferred from paternity analysis in a mixed oak stand of Quercus robur L. and Q. petraea (Matt.) Liebl. Molecular Ecology 8: 831-841.

TAYlor, J. S., J. M. H. DuRKin and F. BREDEN (1999): The death of a microsatellite: a phylogenetic perspective on microsatellite interruptions. Molecular Biology and Evolution 16: 567-572.

Thompson, J. D., D. G. Higgins and T. J. Gibson (1994): CLUSTAL W: improving the sensitivity of progressive multiple sequence alignment through sequence weighting, positions-specific gap penalties and weight matrix choice. Nucleic Acids Research 22: 4673-4680.

VAn Der Schoot, J., M. Pospís̆Ková, B. Vosman and M. J. M. SMULDERS (2000): Development and characterization of microsatellite markers in black poplar (Populus nigra L.). Theoretical and Applied Genetics 101: 317-322.

Victory, E., J. C. Glaubitz, O. E. JR Rhodes and K. Woeste (2006): Genetic homogeneity in Juglans nigra (Juglandaceae) at nuclear microsatellites. American Journal of Botany 93: 118-126.

Woeste, K., R. Burns, O. Rhodes and C. Michler (2002): Thirty polymorphic nuclear microsatellite loci from black walnut. Journal of Heredity 93: 58-60.

WRIGHT, S. (1951): The genetical structure of populations. Annals of Eugenics 15: 323-354. 